\title{
Climate Change Influencing the Potential Distribution of a Brazilian Savanna Indicator Species
}

\author{
Cristiano Rodrigues Reis ${ }^{1}$ (D), Marcelo Leandro Bueno ${ }^{2}$ (D), \\ Lucas Fernandes Rocha ${ }^{3}$ (D), Lidia Gabriella Santos ${ }^{4}$ (D), Eric Bastos Gorgens
}

${ }^{1}$ TREELAB, Departamento de Engenharia Florestal, Universidade Federal do Vales do Jequitinhonha e Mucuri - UFVJM, Diamantina/MG, Brasil

${ }^{2}$ Laboratório de Botânica, Universidade Estadual do Mato Grosso do Sul, Unidade Mundo Novo - UEMS, Mundo Novo/MS, Brasil ${ }^{3}$ Laboratório de Conservação Genetica de Espécies Arbóreas, Departamento de Ciências Florestais, Universidade Federal de Lavras - UFLA, Lavras/MG, Brasil

${ }^{4}$ Laboratório de Medição e Gestão Florestal, Departamento de Engenharia Florestal, Universidade Federal dos Vales do Jequitinhonha e Mucuri - UFVJM, Diamantina/MG, Brasil

\begin{abstract}
The objective of this study was to model the potential effect of future climate change on the distribution of a tree species indicator of Cerrado. For the modeling, we used 488 occurrence points of the species and also bioclimatic variables corresponding to 2050 and 2070, for the more optimistic and pessimistic scenarios. All generated models were classified as consistent, getting an area under curve higher than 0.90 . The current modeling of Connarus suberosus showed that $88 \%$ of the area with a high probability of species occurrence is inside the Cerrado domain. Future projections suggest losses in the environmental suitability area around $40.8 \%$ and $44.8 \%$ in the optimistic scenario, $61.6 \%$ and $81.6 \%$ in the pessimistic scenario considering 2050 and 2070, respectively. Furthermore, we found a tendency of the C. suberosus to move in the Atlantic Forest direction. This modeling is an alert that the C. suberosus will suffer from future climate change.
\end{abstract}

Keywords: bioclimatic variable, Connarus suberosus, environmental suitability, Neotropical savanna, maximum entropy. 


\section{INTRODUCTION}

Several scientists believe that extremes of hot temperatures will occur with higher frequency and duration. The increment on global warming is associated with the rising on the concentration of greenhouse gases caused by anthropic interventions (Stocker et al., 2013). Rapid changes in the climatic conditions can harm the migration of species to environments suitable for its adaptation. These effects become even more emphasized on tree species, which usually are much more adapted to specific microclimatic conditions (Buckeridge et al., 2007).

Understanding geographic patterns of species distribution is a fundamental key for the identification of areas with elevated conservation importance (Siqueira \& Durigan, 2007). Also, it may help to recognize the susceptibility of areas to environmental and anthropic changes (Cupertino-Eisenlohr et al., 2017) on the potential risk of species extinction (Thomas et al., 2004; Malcolm et al., 2006; Ohlemüller et al., 2008) and how it can affect the economy of communities that depend on these resources to live (Nabout et al., 2011, 2016).

The potential species distribution modeling (SDM) using bioclimatic variables is an efficient way to study geographic distribution of species (e.g. Elith et al., 2006; Pearson et al., 2007; Werneck et al., 2012). Moreover, SDM can be applied as a tool to indicate how environmental changes can modify the characteristics of forests, including changes in spatial distribution (Williams et al., 2003). Approaches applying models can predict the geographic distribution of communities and tropical forests structure (Dubuis et al., 2011), including assessments about dynamics of phytogeographic patterns (Collevatti et al., 2012a). That includes the conversion of the Latin American savannas into different biomes (Moncrieff et al., 2016) and the savannization process of tropical forests in Brazil (Salazar et al., 2007).

The Cerrado domain, also known as the neotropical savanna, has suffered from continuous deforestation during the last decades, becoming one of the most endangered savannas in the world and one of the most threatened biomes in Brazil (Silva \& Bates, 2002; Aguiar et al., 2016).

The Connarus suberosus Planch is a typical Cerrado vegetation species (Matheus et al., 2009) reported with high indicator value (Bueno et al.,
2016). Many indicator species can be used to monitor trends in forest dynamics (Carignan \& Villard, 2002) and to characterize the environmental preferences (Cáceres et al., 2010). Furthermore, species strongly associated with particular habitat features could also be useful as an indicator for conservation purposes, land management, landscape mapping or design of natural reserves (Dufrêne \& Legendre, 1997; Carignan \& Villard, 2002; Cáceres et al., 2010).

The objective of this study was to evaluate the effect of future climate change on the C. suberosus distribution. The modeling was performed for both the most optimistic and the most pessimistic IPCC scenarios in terms of temperature increment, projecting to 2050 and 2070 .

\section{MATERIAL AND METHODS}

Covering around 2 million square kilometers, the Cerrado domain occupies approximately $22 \%$ of the Brazilian territory and works as a corridor between the Amazon and Atlantic Forest domains (Ribeiro \& Walter, 2008). The typical Cerrado vegetation grows on acid and dystrophic soils (Oliveira-Filho \& Ratter, 2002; Mendonça et al., 2008) and is considered the richest tropical savanna in the world in terms of biodiversity (Klink \& Machado, 2005).

This biome has a high level of endemism for many groups of animals and plants (Machado et al., 2004). Studies have already listed more than 11,000 vascular plants species (Mendonça et al., 2008) where approximately $44 \%$ of the species is endemic (Klink \& Machado, 2005). The elevated presence of endemic species and the constant process of habitat loss classifies the Cerrado domain as one of the global biodiversity hotspots (Myers et al., 2000).

An important Cerrado species is the Connarus suberosus Planch (Matheus et al., 2009). This species belongs to the Connaraceae botanic family and can reach $7 \mathrm{~m}$ in height. The flowering happens between August and October. The seeds have low germination and its fruits get mature between November and February (Lorenzi, 2002; Matheus et al., 2009). The species is listed between the top 10 species of the typical Cerrado vegetation (Bueno et al., 2016). Due to the large number of records within this biome this species 
can be considered an indicative of the Cerrado domain (Matheus et al., 2009).

We extracted 488 occurrence points from NeoTropTree (Oliveira-Filho, 2017) to be used during the modeling step (Figure 1). NeoTropTree database contains tree species checklist gathered from literature and prepared for sites distributed across the Neotropical region. It has been used as support for several researches, such as floristic and geographic patterns, phylogenetic diversity and conservation strategies (see details at Oliveira-Filho, 2017).

We used rasters files of 19 bioclimatic variables with resolution of $1 \mathrm{Km}$ (Hijmans et al., 2005). To avoid collinearity, we excluded variables which correlation is above $90 \%$ based on ecological relevance. From the 19 bioclimatic variables we ended up with 10 : annual mean temperature, mean diurnal range, isothermality, maximum temperature of warmest month, annual temperature range, annual precipitation, driest month precipitation, precipitation seasonality, precipitation of warmest quarter and precipitation of coldest quarter.

The modeling process was based on the principle of maximum entropy, considering only the observed data. The algorithm subscribes the known distribution by the estimated distribution, avoiding the insertion of unfounded constraints (Phillips et al., 2006; Pearson et al., 2007). The presence-only data are more appropriate for predicting potential distribution such as climate change impact applications (Miller, 2010) and this characteristic was used for the choice of the algorithm (Bueno et al., 2016). Besides, many studies have already demonstrated the effectiveness of the MaxEnt approach on ecological niche modeling. The algorithm is also considered robust and consistent (Elith et al., 2006; Pearson et al., 2007; Werneck et al., 2012; Aguiar et al., 2016; Bueno et al., 2016) and was implemented in the MaxEnt 3.4 software. We used replicated subsample, the minimum training presence threshold, and a maximum of 5000 iterations. The data were divided into $75 \%$ for training and $25 \%$

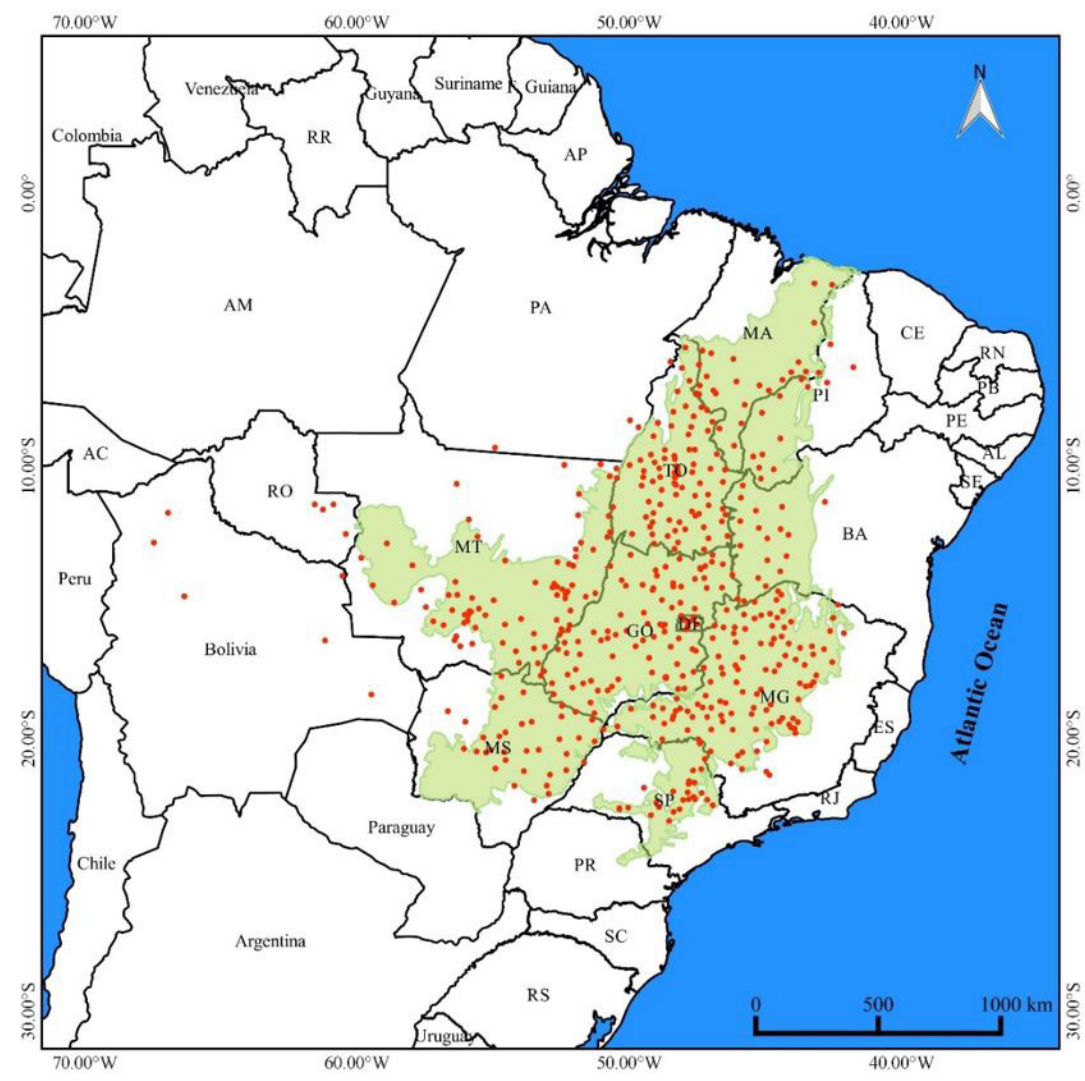

Figure 1. Geographic distribution of Connarus suberosus showing the 488 occurrence points. The shaded area and the red points indicate the Brazilian Cerrado domain and the species occurrence points, respectively. 
for validation. So, we applied the maximum entropy algorithm on 366 occurrence points to estimate the species distribution and the remaining 122 points were used to validation. Twenty-five models were generated and the analysis was performed averaging the constructed models results.

In order to model the current C. suberosus distribution, we used climatic layers based on an average value from 1960 to 1990 Worldclim data. The climate change forecast was based on the climate projections of the Fifth Intergovernmental Panel on Climate Change ( $\mathrm{IPCC}_{5}$ ) from the Global Climate Models (GCMs) for four representative pathways of greenhouse gases concentration (RCP) (Worldclim, 2017). The possible effects of climate change were evaluated using the RCP 2.6 and 8.5 for both 2050 and 2070 (Community Climate System Model CCSM 4.0; CESM, 2017). The RCP 2.6 is the most optimistic scenario and represents an increase in the global temperature varying from 0.3 to $1.7^{\circ} \mathrm{C}$ until 2100. However, the RCP 8.5 shows a more pessimistic scenario with an increase in the global temperature ranging from 1.4 to $4.8^{\circ} \mathrm{C}$ until 2100 (Stocker et al., 2013).

The model validation was performed analyzing the receiver operating characteristic curve (ROC). The ROC curve evaluates the absence of commission error (specificity) and the absence of omission error (sensitivity), providing the predictive performance of the model on all possible thresholds (area under the curve value - AUC). The AUC value varies between 0 and 1 ; for values below 0.5 , the adjusted model is worse than a random model. For values closer to 1 , the model used is more efficient than a random model (Elith et al., 2006; Phillips, 2017). Additionally, we calculated the loss of area reclassifying the maps according to the probability of occurrence greater than 0.5 , which means a suitability varying from moderate to high.

\section{RESULTS}

According to the jackknife test, the four most important variables for modeling were: isothermality, temperature annual range, annual precipitation and precipitation seasonality. The models had a good adjustment and were classified as consistent, getting an AUC higher than 0.90 for all generated models (Current model, AUC $=0.908$; RCP 2.6 model for year 2050, AUC $=0.908$; RCP 8.5 model for year 2050, AUC $=0.902 ;$ RCP 2.6 model for year 2070, $\mathrm{AUC}=0.905$; and RCP 8.5 model for year 2070, AUC $=0.904$ ).

Considering only the current predictive model, more than $99 \%$ of the total area with probability (probability of occurrence $>0.5$ ) to finding C. suberosus is found in Brazil (Figure 2), being $88 \%$ included in the Cerrado domain. Small areas for species occurrence can also be found in the Atlantic Forest (7.7\%), Amazon (3.2\%), Caatinga and Pantanal domains (1\% including both).

Comparing the current distribution model and RCP 2.6, distributions showed a reduction of $40.8 \%$ of the areas suitable for C. suberosus for 2050 (Figure 3a) and a reduction of $44.8 \%$ for 2070 (Figure $3 \mathrm{~b}$ ). The RCP 8.5 scenario indicates a reduction of $61.6 \%$ of suitable areas for 2050 (Figure 3c) and 81.6\% for 2070 (Figure 3d).

All future scenarios show that the C. suberosus suitability will be restricted in the Atlantic Forest direction. The models generated for the RCP 8.5 scenario indicated some fragments with a probability of $C$. suberosus occurrence greater than 0.5 on the Eastern and Southern Cerrado domain.

The RCP 2.6 projected for 2070 and RCP 8.5 projected for 2070 showed C. suberosus occurring in the West of Bahia state and in large portions of Goiás and Minas Gerais states (Figure 4).

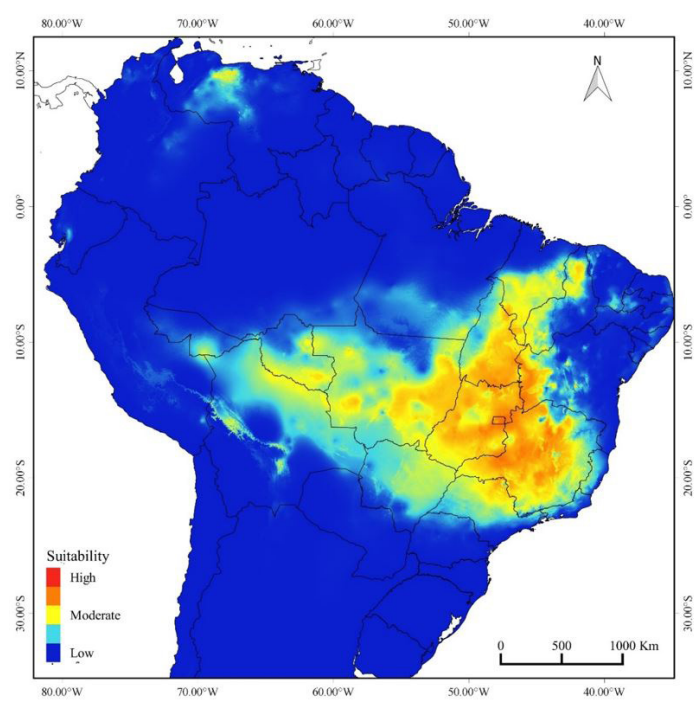

Figure 2. Current occurrence probability for the Connarus suberosus species on Neotropics. 

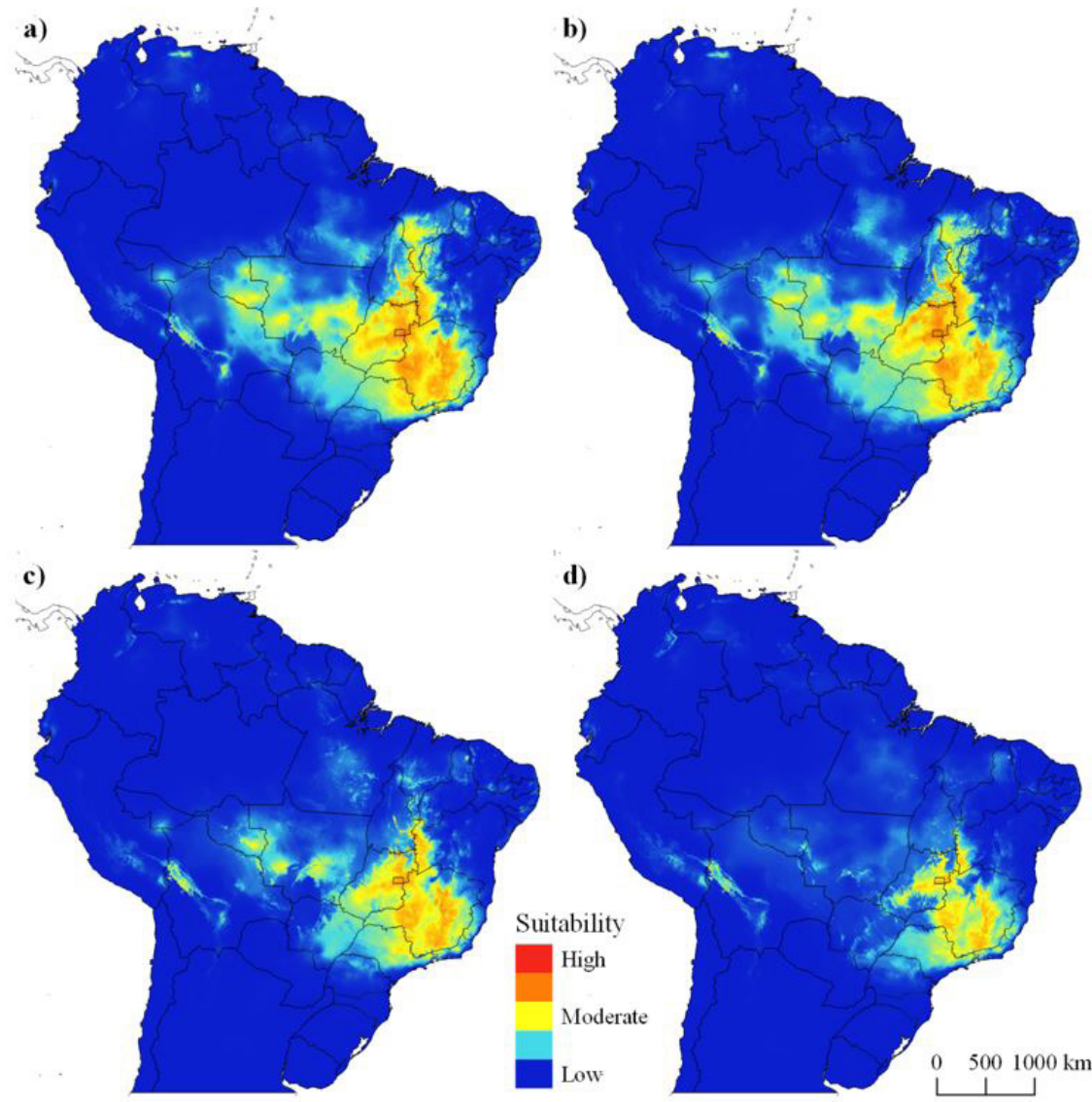

Figure 3. Potential distribution of Connarus suberosus on four representative pathways of greenhouse gases concentration scenarios: a) increase in the global temperature varying from 0.3 to $1.7^{\circ} \mathrm{C}$ for 2050 ; b) increase in the global temperature varying from 0.3 to $1.7^{\circ} \mathrm{C}$ for 2070 ; c) increase in the global temperature ranging from 1.4 to $4.8^{\circ} \mathrm{C}$ for 2050 ; and d) increase in the global temperature ranging from 1.4 to $4.8^{\circ} \mathrm{C}$ for 2070 .

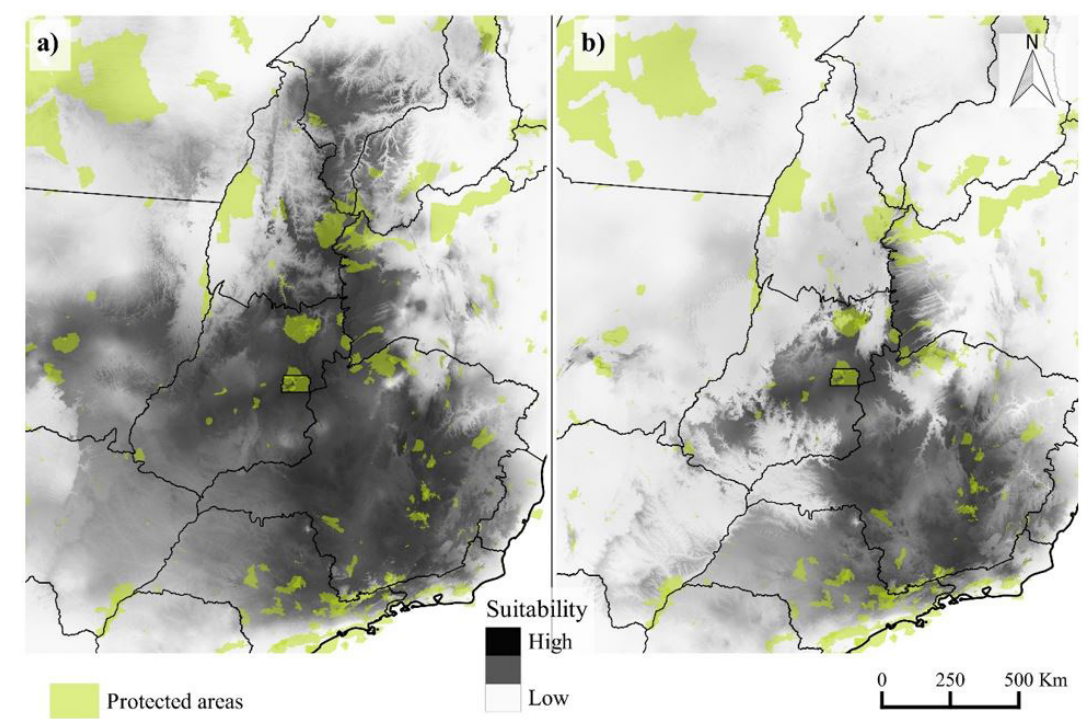

Figure 4. Potential distribution of Connarus suberosus and protected areas location. a) C. suberosus suitability projected for RCP 2.6 in 2050; and b) C. suberosus suitability projected for RCP 8.5 in 2070. 


\section{DISCUSSION}

The model performance was better than a random model, exhibiting suitable predictive power. Although the C. suberosus occurrence extends to Pantanal domain, it is a species that represents a Cerrado typical (lato sensu) vegetation (IPJBRJ, 2018). SDM have been used to show how Cerrado is responding to the climate and precipitation changes (Collevatti et al., 2012b, 2015; Bueno et al., 2016; Buzatti et al., 2017; Lima et al., 2017). Studies are reporting that the Cerrado domain will lose a considerable amount of area due to climate change. The area loss in the Cerrado domain and movement towards the Atlantic Forest biome are consistent with the results presented by Lima et al. (2017), analyzing another indicator species Tabebuia aurea.

Comparing the current model against the future models obtained for the $C$. suberosus we can visualize the proportion of area loss due to the climate change. Thomas et al. (2004) pointed an extinction risk ranging between $48 \%$ and $56 \%$ for Cerrado species, and Siqueira \& Peterson (2003) are suggesting 90\% of area loss in aggressive scenarios. Predictive models for bats, birds, and trees have shown similar patterns, showing suitable areas for those species concentrating in Goiás, Minas Gerais and São Paulo states, moving to other biome limits (Siqueira \& Peterson, 2003; Marini et al., 2009; Aguiar et al., 2016). Forecasts based on climatic scenarios for 2070 have shown not only a reduction for the actual savannas domains (Moncrieff et al., 2016) but also an increase of the savannization process of tropical forests as a consequence of climate changes (Salazar et al., 2007). According to Moncrieff et al. (2016), 57\% of savannas domain in South America may be transformed into other biomes by 2070 .

The Cerrado domain is one of the Brazilian's most devastated biomes, caused mainly by anthropogenic deforestation to land use changing (Thomas et al., 2004; Malcolm et al., 2006; Sano et al., 2008; Fernandes et al., 2016). Negative impacts on biological diversity and ecosystem stability should be expected, in addition to landscape modification due to local and regional climatic conditions (Parry et al., 2007). The enormous importance of the Brazilian Cerrado for agribusiness threats the biome conservation (Aguiar et al., 2016; Fernandes et al., 2016). The Cerrado biodiversity depends not only on the climatic conditions but also of the species ability to resist habitat loss and fragmentation (Thomas et al., 2004; Malcolm et al., 2006).
The C. suberosus species has economic potential and has been reported as an important species for multiple uses (Aquino et al., 2007; Matheus et al., 2009; Silva et al., 2015). Beyond the effect of climate change, we still need to investigate the influence of its economic exploitation. Future climate change scenarios for the Cerrado domain have shown the possibility of area loss and geographic distribution reduction considering the economic use of some species (e.g. Hacornia speciosa Gomez and Lychnophora ericoides Less.) (Simon et al., 2013; Nabout et al., 2016). The distribution displacement of the species of economic interest can affect not only the biodiversity, but also local economies (Nabout et al., 2011, 2016).

Avoid the biodiversity losses associated with climate change is a goal that must be pursued. The protected areas map in the results section showed that there are many places with high suitability of C. suberosus occurrence out of those areas. The creation of new protected areas and improving conservative practices should be urgently considered. Investing on projects for biodiversity conservation and maintenance of the structure and ecosystems function are important strategies for the achievement of these goals (Parry et al., 2007). Therefore, a landscape approach is essential to implement successful strategies for habitats restoration, ecological corridors implementation and conservation areas creation (Thuiller et al., 2008). Fragments of natural habitats that show an environmental suitability for Cerrado species occurrence should be maintained as conservation areas even if they are located in the agricultural areas (Aguiar et al., 2016). Minas Gerais state holds the most suitable areas for $C$. suberosus for both RCP scenarios, mainly in the regions close to Serra da Canastra, Serra do Espinhaço and Serra da Mantiqueira. Those areas have already protected areas most likely to the species occurrence (Figure 4).

Our models evidence possible competition between the C. suberosus and the Atlantic Forest species in the future, corroborating other studies findings (Scarano \& Ceotto, 2015; Lima et al., 2017).

\section{CONCLUSIONS}

It is reasonable to expect a concretization of the movement detected by both scenarios (optimistic and pessimistic). Keep monitoring the Connarus suberosus occurrence to validate this study's finding is crucial to determine the velocity in which the area loss and 
distribution reduction is happening. Actions aiming the creation of protected areas and improvement of conservancy practices are essential to ensure not only the species survival but also the biome biodiversity preservation. Ecological corridors should be urgently implemented to support the species migration to suitability areas.

\section{ACKNOWLEDGEMENTS}

We are thankful to the treelab and the Laboratory of Forest Measurement and Management, both from UFVJM, and the Laboratory of Ecology and Evolution of Plants from UFV. We are also grateful to UFVJM, FAPEMIG, CAPES and CNPq for the financial resources.

\section{SUBMISSION STATUS}

Received: 23 feb., 2018

Accepted: 30 jun., 2018

\section{CORRESPONDENCE TO}

\section{Cristiano Rodrigues Reis}

Centro de Métodos Quantitativos, Programa de Pós-Graduação em Recursos Flroestais, Departamento de Ciências Florestais, Escola Superior de Agricultura Luiz de Queiroz, Universidade de São Paulo - USP, Avenida Pádua Dias, 11, CEP 13418-900, Piracicaba, SP, Brasil e-mail: cristiano.reis@usp.br

\section{FINANCIAL SUPPORT}

FAPEMIG, CAPES and CNPq.

\section{REFERENCES}

Aguiar LMS, Bernard E, Ribeiro V, Machado RB, Jones G. Should I stay or should I go? Climate change effects on the future of Neotropical savannah bats. Global Ecology and Conservation 2016; 5: 22-33. http://dx.doi.org/10.1016/j. gecco.2015.11.011.

Aquino FG, Walter BMT, Ribeiro JF. Espécies vegetais de uso múltiplo em reservas legais de cerrado-Balsas, MA. Revista Brasileira de Biociências 2007; 5(S1): 147-149.

Buckeridge MS, Mortari LC, Machado MR. Respostas fisiológicas de plantas às mudanças climáticas: alterações no balanço de carbono nas plantas podem afetar o ecossistema? In: Rego GM, Negrelle RRB, Morellato LPC, editores. Fenologia - Ferramenta para conservação e manejo de recursos vegetais arbóreos. Colombo: Embrapa Florestas; 2007.

Bueno ML, Pennington RT, Dexter KG, Kamino LHY, Pontara V, Neves DM et al. Effects of quaternary climatic fluctuations on the distribution of Neotropical savanna tree species. Ecography 2016; 39(1): 1-12.

Buzatti RSO, Lemos-Filho JP, Bueno ML, Lovato MB. Multiple Pleistocene refugia in the Brazilian cerrado: evidence from phylogeography and climatic nichemodelling of two Qualea species (Vochysiaceae). Botanical Journal of the Linnean Society 2017; 185(3): 307-320. http://dx.doi. org/10.1093/botlinnean/box062.

Cáceres M, Legendre P, Moretti M. Improving indicator species analysis by combining groups of sites. Oikos 2010; 119(10): 1674-1684. http://dx.doi.org/10.1111/j.16000706.2010.18334.x.

Carignan V, Villard MA. Selecting indicator species to monitor ecological integrity: a review. Environmental Monitoring and Assessment 2002; 78(1): 45-61. http:// dx.doi.org/10.1023/A:1016136723584. PMid:12197640.

Collevatti RG, Lima-Ribeira MS, Souza-Neto AC, Franco AA, Oliveira G, Terribile LC. Recovering the demographical History of a Brazilian Cerrado tree species Caryocar brasiliense: coupling ecological niche modeling and coalescent analyses. Natureza \& Conservação 2012b; 10(2): 169-176. http://dx.doi.org/10.4322/natcon.2012.024.

Collevatti RG, Terribile LC, Lima-Ribeiro MS, Nabout JC, Oliveira G, Rangel TF et al. A coupled phylogeographical and species distribution modelling approach recovers the demographical history of a Neotropical seasonally dry forest tree species. Molecular Ecology 2012a; 21(23): 5845-5863. http://dx.doi.org/10.1111/mec.12071. PMid:23094833.

Collevatti RG, Terribile LC, Rabelo SG, Lima-Ribeiro MS. Relaxed random walk model coupled with ecological niche modeling unravel the dispersal dynamics of a Neotropical savanna tree species in the deeper Quaternary. Frontiers of Plant Science 2015; 6(1): 653. http://dx.doi.org/10.3389/ fpls.2015.00653. PMid:26379681.

Community Earth System Model - CESM. CESM models [online]. 2017 [cited 2017 April] Available from: http:// www.cesm.ucar.edu/models/ccsm4.0/

Cupertino-Eisenlohr MA, Vinícius-Silva R, Meireles LD, Eisenlohr PV, Meira-Neto JAA, Santos-Gonçalves AP. Stability or breakdown under climate change? A key group of woody bamboos will find suitable areas in its richness center. Biodiversity and Conservation 2017; 26(8): 1845-1861. http://dx.doi.org/10.1007/s10531-017-1332-x.

Dubuis A, Pottier J, Rion V, Pellissier L, Theurillat J, Guisan A. Predicting spatial patterns of plant species richness: a comparison of direct macroecological and species stacking modelling approaches. Diversity \& Distributions 
2011; 17(6): 1122-1131. http://dx.doi.org/10.1111/j.14724642.2011.00792.x.

Dufrêne M, Legendre P. Species assemblages and indicator species: the need for a flexible asymmetrical approach. Ecological Monographs 1997; 67(3): 345-366. http://dx.doi. org/10.2307/2963459.

Elith J, Graham CH, Anderson RP, Dudík M, Ferrier S, Guisan A et al. Novel methods improve prediction of species' distributions from occurrence data. Ecography 2006; 29(2): 129-151. http://dx.doi.org/10.1111/j.2006.09067590.04596.x

Fernandes GW, Pedroni F, Sanchez M, Scariot A, Aguiar LMS, Ferreira G et al. Cerrado: em busca de soluções sustentáveis Rio de Janeiro: Vertentes Produções Artísticas; 2016.

Hijmans RJ, Cameron SE, Parra JL, Jones PG, Jarvis A. Very high resolution interpolated climate surfaces for global land areas. International Journal of Climatology 2005; 25(15): 1965-1978. http://dx.doi.org/10.1002/joc.1276.

Instituto de Pesquisas Jardim Botânico do Rio de Janeiro - IPJBRJ. Flora do Brasil 2020 - em construção [online]. Rio de Janeiro: JBRJ; 2018 [cited 2018 Feb 22]. Available from: http://floradobrasil.jbrj.gov.br/

Klink CA, Machado RB. Conservation of the Brazilian Cerrado. Conservation Biology 2005; 19(3): 707-713. http:// dx.doi.org/10.1111/j.1523-1739.2005.00702.x.

Lima JS, Ballesteros-Mejia L, Lima-Ribeiro MS, Collevatti RG. Climatic changes can drive the loss of genetic diversity in a Neotropical savanna tree species. Global Change Biology 2017; 23(11): 4639-4650. http://dx.doi. org/10.1111/gcb.13685. PMid:28295840.

Lorenzi H. Árvores brasileiras: manual de identificação e cultivo de plantas arbóreas nativas do Brasil. Vol 2. Nova Odessa: Plantarum; 2002.

Machado RB, Ramos-Neto MB, Pereira PGP, Caldas EF, Gonçalves DA, Santos NS et al. Estimativas de perda da área do Cerrado brasileiro. Brasília: Conservação Internacional; 2004.

Malcolm JR, Liu C, Neilson RP, Hansen L, Hannah L. Global warming and extinctions of endemic species from biodiversity hotspots. Conservation Biology 2006; 20(2): 538-548. http://dx.doi.org/10.1111/j.1523-1739.2006.00364.x. PMid:16903114.

Marini MA, Barbet-Massin M, Lopes LE, Jiguet F. Predicted climate-driven bird distribution changes and forecasted conservation conflicts in a neotropical savanna. Conservation Biology 2009; 23(6): 1558-1567. http://dx.doi. org/10.1111/j.1523-1739.2009.01258.x. PMid:19500118.

Matheus MT, Bacelar M, Oliveira SAS, Lopes JC. Morfologia de frutos, sementes e desenvolvimento pósseminal de cabelo-de-negro: Connarus suberosus Planch. (Connaraceae). Cerne 2009; 15(4): 407-412.

Mendonça RC, Felfili JM, Walter BMT, Silva-Júnior MCS, Rezende AV, Filgueiras TS et al. Flora vascular do
Bioma Cerrado: checklist com 12.356 espécies. In: Sano SM, Almeida SP, Ribeiro JF, editores. Cerrado: ecologia e flora. Planaltina: Embrapa Cerrados; 2008.

Miller J. Species distribution modeling. Geography Compass 2010; 4(6): 490-509. http://dx.doi.org/10.1111/j.17498198.2010.00351.x.

Moncrieff GR, Scheiter S, Langan L, Trabucco A, Higgins SI. The future distribution of the savannah biome: modelbased and biogeographic contingency. Philosophical Transactions of the Royal Society of London. Series B, Biological Sciences 2016; 371(1703): 1-10. PMid:27502376.

Myers N, Mittermeier RA, Mittermeier CG, Fonseca GAB, Kent J. Biodiversity hotspots for conservation priorities. Nature 2000; 403(6772): 853-858. http://dx.doi. org/10.1038/35002501. PMid:10706275.

Nabout JC, Magalhães MR, Gomes MAA, Cunha HF. The impact of global climate change on the geographic distribution and sustainable harvest of Hancornia speciosa Gomes (Apocynaceae) in Brazil. Environmental Management 2016; 57(4): 814-821. http://dx.doi.org/10.1007/s00267016-0659-5. PMid:26796699.

Nabout JC, Oliveira G, Magalhães MR, Carina TL, Almeida FAS. Global climate change and the production of "pequi" fruits (Caryocar brasiliense) in the Brazilian Cerrado. Natureza \& Conservação 2011; 9(1): 55-60. http://dx.doi. org/10.4322/natcon.2011.006.

Ohlemüller R, Anderson BJ, Araújo MB, Butchart SH, Kudrna O, Ridgely RS et al. The coincidence of climatic and species rarity: high risk to small-range species from climate change. Biology Letters 2008; 4(5): 568-572. http:// dx.doi.org/10.1098/rsbl.2008.0097. PMid:18664421.

Oliveira-Filho AT, Ratter JA. Vegetation physiognomies and woody flora of the Cerrado Biome. In: Oliveira PS, Marquis RJ, editores. The cerrados of Brazil: ecology and natural history of a neotropical savanna. New York: Columbia University Press; 2002. http://dx.doi.org/10.7312/ oliv12042-007.

Oliveira-Filho AT. NeoTropTree - Flora arbórea da Região Neotropical: um banco de dados envolvendo biogeografia, diversidade e conservação [online]. Belo Horizonte: Universidade Federal de Minas Gerais; 2017 [cited 2017 Apr 10]. Available from: http://www.icb.ufmg.br/treeatlan/

Parry ML, Canziani OF, Palutikof JP, Van der Linden PJ, Hanson CE, editores. Climate change 2007: impacts, adaptation, and vulnerability - Contribution of working group II - 4th assessment report of the Intergovernmental Panel on Climate Change - IPCC. Cambridge: University Press; 2007.

Pearson RG, Raxworthy CJ, Nakamura M, Peterson AT. Predicting species distributions from small numbers of occurrence records: a test case using cryptic geckos in Madagascar. Journal of Biogeography 2007; 34(1): 102117. http://dx.doi.org/10.1111/j.1365-2699.2006.01594.x. 
Phillips SJ, Anderson RP, Schapire RE. Maximum entropy modeling of species geographic distributions. Ecological Modelling 2006; 190(3-4): 231-259. http:// dx.doi.org/10.1016/j.ecolmodel.2005.03.026.

Phillips SJ. A brief tutorial on maxent [online]. 2017 [cited 2017 Apr 10] Available from: http://biodiversityinformatics. amnh.org/open_source/maxent/

Ribeiro JF, Walter BMT. As principais fitofisionomias do Bioma Cerrado. In: Sano SM, Almeida SP, Ribeiro JF, editores. Cerrado: ecologia e flora. Planaltina: Embrapa Cerrados; 2008.

Salazar LF, Nobre CA, Oyama MD. Climate change consequences on the biome distribution in tropical South America. Geophysical Research Letters 2007; 34(9): 1-6. http://dx.doi.org/10.1029/2007GL029695.

Sano EE, Rosa R, Brito JLS, Ferreira LG. Mapeamento semidetalhado do uso da terra do Bioma Cerrado. Pesquisa Agropecuária Brasileira 2008; 43(1): 153-156. http://dx.doi. org/10.1590/S0100-204X2008000100020.

Scarano FR, Ceotto P. Brazilian atlantic forest: impact, vulnerability, and adaptation to climate change. Biodiversity and Conservation 2015; 24(9): 2319-2331. http://dx.doi. org/10.1007/s10531-015-0972-y.

Silva AF, Rabelo MFR, Enoque MM. Diversidade de angiospermas e espécies medicinais de uma área de Cerrado. Revista Brasileira de Plantas Medicinais 2015; 17(4): 1016-1030. http://dx.doi.org/10.1590/1983-084x/14_115.

Silva JMC, Bates JM. Biogeographic patterns and conservation in the South American Cerrado: a tropical savanna hotspot: the Cerrado, which includes both forest and savanna habitats, is the second largest South American biome, and among the most threatened on the continent. Bioscience 2002; 52(3): 225-233. http://dx.doi. org/10.1641/0006-3568(2002)052[0225:BPACIT]2.0.CO;2.

Simon LM, Oliveira G, Barreto BS, Nabout JC, Rangel TFLVB, Diniz-Filho JAF. Effects of global climate changes on geographical distribution patterns of economically important plant species in Cerrado. Revista Árvore
2013; 37(2): 267-274. http://dx.doi.org/10.1590/S010067622013000200008 .

Siqueira MF, Durigan G. Modelagem da distribuição geográfica de espécies lenhosas de cerrado no Estado de São Paulo. Revista Brasileira de Botanica. Brazilian Journal of Botany 2007; 30(2): 233-243. http://dx.doi.org/10.1590/ S0100-84042007000200008.

Siqueira MF, Peterson AT. Consequences of global climate change for geographic distributions of Cerrado tree species. Biota Neotropica 2003; 3(2): 1-14. http://dx.doi. org/10.1590/S1676-06032003000200005.

Stocker TF, Qin D, Plattner GK, Tignor M, Allen SK, Boschung J et al., editores. Climate change 2013: the physical science basis - Contribution of working group I5th assessment report of the Intergovernmental Panel on Climate Change IPCC. Cambridge: University Press; 2013.

Thomas CD, Cameron A, Green RE, Bakkenes M, Beaumont LJ, Collingham YC et al. Extinction risk from climate change. Nature 2004; 427(6970): 145-148. http://dx.doi. org/10.1038/nature02121. PMid:14712274.

Thuiller W, Albert C, Araújo MB, Berry PM, Cabeza M, Guisan A et al. Predicting global change impacts on plant species' distributions: Future challenges. Perspectives in Plant Ecology, Evolution and Systematics 2008; 9(3-4): 137-152. http://dx.doi.org/10.1016/j.ppees.2007.09.004.

Werneck FP, Nogueira C, Colli GR, Sites JW Jr, Costa GC. Climatic stability in the Brazilian Cerrado: implications for biogeographical connections of South American savannas, species richness and conservation in a biodiversity hotspot. Journal of Biogeography 2012; 39(9): 1695-1706. http:// dx.doi.org/10.1111/j.1365-2699.2012.02715.x.

Williams SE, Bolitho EE, Fox S. Climate change in Australian tropical rainforests: an impending environmental catastrophe. Proceedings. Biological Sciences 2003; 270(1527): 1887-1892. http://dx.doi.org/10.1098/rspb.2003.2464. PMid:14561301.

WORLDCLIM. Global climate data: free climate data for ecological modeling and GIS [online]. 2017 [cited 2017 Apr 10]. Available from: http://www.worldclim.org/ 